\title{
Parents' Communication Strategies in Building Internet Media Literacy for Youth in Muslim Family in Tanjung Mulia Medan Deli
}

\author{
$\underline{\text { Abdul Karim Batubara }}{ }^{1}$, Suwardi Lubis ${ }^{2}$, Syukur Kholil ${ }^{3}$ \\ ${ }^{1}$ Ph.D Student in State Islamic University of North Sumatera, Medan, Indonesia \\ ${ }^{2}$ Lecturer in Universitas Sumatera Utara, Medan, Indonesia \\ ${ }^{3} \mathrm{Ph} . \mathrm{D}$ Student in State Islamic University of North Sumatera, Medan, Indonesia \\ Email: karimbatubara@yahoo.com
}

\begin{abstract}
:
The research aims to find out the communication strategies carried out by Muslim family towards youth in accessing the internet, analyzing internet content, evaluating internet content, responding to internet content and finding the results of communication strategies carried out by Muslim family in building internet media literacy for youth in Tanjung Mulia Medan Deli. This research uses field research with a qualitative approach. The informants of this study is one family located in Tanjung Mulia Subdistrict, Medan Deli. Determination of informants using purposive sampling techniques. Research data collection using interviews and observation. While the data analysis technique used is using Spradley Model data analysis. To maintain data validity, data triangulation techniques are used. The results of the study revealed that parents' communication strategies in controlling internet access carried out by their children by providing time limits for their children in accessing the internet. Parents still provide supervision, time restrictions and remind their children to pay attention to internet usage. Communication strategies applied by parents towards analyzing internet content that is often accessed by freeing their children in choosing and accessing internet content and discussing with parents when they find new information and negative content. The strategy taken by parents in evaluating internet content for children is to choose internet content and discuss it with other family members. The communication strategies of parents in responding to internet content carried out by their children is by giving advice on an ongoing basis and giving a warning to their children. It can make their children feel cared for by their parents. As well as to build a Communication Strategies of Media Literacy for Youth in Muslim Family by using Islamic communication approach that is sourced from the Al Qur'an and Hadith.
\end{abstract}

Keywords:

communication strategies; media literacy; family communication; internet

\section{Introduction}

Many teenagers in Tanjung Mulia, Medan Deli District, have used the internet for their respective activities and purposes. Of course as is usual with the media, the internet has positive and negative impacts on its use. The positive impact of using the internet for teenagers is the wealth of knowledge available to them, which people from past generations did not have access to. Websites that are educational in nature, or provide information on many topics, such as Wikipedia, have advanced in popularity over the past few years and teens make up a large part of that. They need help on the topic for their course, or who are only generally interested in reading about a particular topic will really reap the benefits of this technological era. 
Some phenomena that are seen by teenagers in Tanjung Mulia, Medan Deli District, are already addicted to using the internet, both applications for social networks such as YouTube, Facebook, Twitter and so on which impact the decline in their interest in learning and practicing their worship. They become lazy, because the time to work helps parents or learning is taken up to surf, so schoolwork is often neglected. Teenagers become too dependent on the internet to do school work. Even though school work that is supposed to be made on your own, is often done by copy paste from a web or blog address.

Addicted to online games often make students forget time, neglect lessons, pay less attention to health such as forgetting to rest, hours of staring at the monitor until the eyes are damaged, lack of sleep and sometimes wasteful spending parents' money, addicted to social networks like Facebook, Twitter, and not few students are entangled in cybercrime.

They spend more time just to access websites that do not make a positive contribution to them. Besides that, teenagers often experience sexual harassment through text and images from the web, there are even teenagers who always access pornographic websites. The minds of adolescents are poisoned by something that can damage morals such as films, pictures, photographs, readings, which are pornographic. Ironically, drug use is increasing and there are some teenagers who become pregnant out of wedlock.

For social interaction, the socialization of adolescents in the community is reduced, because adolescents become more comfortable and comfortable socializing in cyberspace. They rarely leave the house, do not want to join the mosque teenagers. They prefer to stare at the computer, laptop and Smartphone to surf until they forget the time. Influence of the internet in mental health unhealthy social patterns if students have become addictive automatically they always spend time in front of a computer monitor so that makes them less sociable with their peers and health will definitely decrease making yourself less rested can be fatal and can even cause Dead.

\section{Review of Literature}

\subsection{Family Communication Model}

Family communication model Family communication proposed by McLeod and Chaffee in Turner and West, proposes social-oriented communication and concept-oriented communication. Socially oriented communication is communication that relatively stresses harmonious relationships and pleasant social relationships in the family. Concept-oriented communication is communication that encourages children to develop views and consider problems.

There are several models of communication in the family, among others. 1) Family communication with a laissez-faire pattern, characterized by low concept-oriented communication, means that children are not directed to develop themselves independently, and are also low in socially oriented communication. This means that children do not foster harmonious relations in the form of interactions with parents. Children and parents lack or do not understand the object of communication, so that it can lead to wrong communication. 2) Family communication with a protective pattern, characterized by low communication in concept orientation, but high communication in social orientation. Compliance and harmony are very important. Children who come from families who use protective patterns in communication are easily persuaded, because they do not learn how to defend or defend their own opinions. 3) Family communication with a pluralistic pattern is a form of family 
communication that runs an open communication model in discussing ideas with all family members, respecting the interests of other members and mutual support. 4) Family communication with consensual patterns, marked by consensus agreement. This form of family communication emphasizes socially oriented and concept-oriented communication. This pattern encourages and provides an opportunity for each family member to express ideas from various points of view, without disrupting the family power structure. Communication model.

Family communication was identified by Olson in Berger as the third dimension that applies to facilitation. That is, it is family communication that determines where the family will be classified according to the two basic dimensions of cohesion and adaptation. Communication within the family needs to be fostered and maintained by each individual involved in it. Communication is the main condition for the continuity of a relationship including family. According to Rae Sedwig in Syaiful Bahri, family communication is an organization that uses words, gestures, intonation of voice, actions to creating image hopes, expressing feelings and sharing understanding.

According to Hendra (2019) Family communication between parents and children occupies an important position in shaping the child's personality. Through family communication, parents do care for their children. Effective family communication means that the communication is going well, smooth and has a positive effect on the child. The positive effect of communication can be seen from the attitudes and behavior of children in everyday life. Conversely, ineffective family communication means that the communication does not have a positive effect on the child, it can even be a negative effect on the child. The effect of negative communication can be seen from the attitudes and behavior of children in everyday life.

\subsection{Parent Mediation}

The requirements that can be summarized in the concept of mediation are always associated with social reality. Mediation involves several different processes. Mediation involves the extension of a second (or third) party to a version of events and conditions that cannot be observed directly for ourselves. The second statement, mediation refers to the efforts of other actors and institutions in society to contact us for their own ends (in our own interests). This applies to politicians and government, advertisers, educators, parents, experts, and all forms of authority. Mediation refers to the indirect way in which we form our perceptions of groups and cultures that are not our own. The main element in mediation as illustrated here is the involvement of several technological tools between our senses and things outside of us.

Mediation also involves some form of relationship, relationships mediated through mass media will be more distant, less personal, and weaker than direct personal ties. Mass media is not a monopoly on the flow of information we receive or they interfere in broader social relations. The initial version of the idea of 'reality mediation' assumes a division between the public sphere, where the views of reality are broadly shared, constructed by means of mass media messages, and the personal sphere, where individuals can speak freely and directly.

In general, the term mediation in the sense of media interferes between us and reality, shows some of the role of the media in connecting us with other experiences. The terms that are often used to describe this role reflect different goals, namely interactivity and effectiveness. Mediation can mean providing information in a neutral way, through negotiations, to manipulation and control experiments. 


\subsection{Organizing Islamic Communication in the Family}

A happy family is reflected in the existence of peace, tranquility, and harmony which is marked by offspring marked by pious or pious offspring, noble morality, intelligent, beneficial to humanity is the desire of every parent. Organizing the family is very necessary to realize a sakinah family. Organizing a sakinah family requires the arts and sciences in organizing, processing and utilizing the appropriate elements of life with the commands and prohibitions of Allah, so that our human beings will be realized. ${ }^{1}$

One of the communication between parents and children, which is described in the Koran when Luqman communicates with children to be a good person: ${ }^{2}$ "And do not turn your face away from humans (because arrogant) and do not walk arrogantly on earth. Verily, Allah does not like arrogant people who pride themselves. Be humble you shall when you walk and soften your voice. The worst sound is the sound of a donkey. "

In this verse, parents can communicate with children. Luqman told his son not to look away from others and not to walk on the face of the earth with pride and pride, and also Luqman told his son to walk simply and soften his voice with separating out the worst sound is the sound of the harsh or donkey.

Deeper education for the formation of a complete human being is the promotion of religious values. Fostering religious values is an overall formation of personal education. So the implementation of fostering religious values is not just in the school or community, but more importantly is in the family. Education in the family is the main and first place of education, from birth the child has begun to receive parental communication with the abilities of the child itself.

\subsection{Parental Mediation}

Mediation is an effort to modify or even prevent negative impacts caused by the mass media. More specifically, Bujizen and Valkenburg suggest that parental mediation is an effective strategy in an effort to prevent the negative impact caused by the internet on children. These efforts are generally carried out by parents, but various elements of the child's environment are also obliged to seek similar things. These elements include siblings, caregivers, teachers, other adults, or game friends. However, given the large role of parents in determining the direction of children's growth and development, the term mediation is more conical in the discussion of parental mediation or parental mediation.

The importance of the role of parents in children's media activities: "The majority of young children's experiences of viewing television and video take place in their own homes and, therefore, parents and likely to make up the shape of young children's perceptions of the status, value and enjoyment, of televisual texts. Forms of mediation, for example, provide comments on alternative activities, discuss social or personal issues raised by the internet, and talk lightly about the internet. Parents, younger siblings, or older siblings can respond to questions with evaluative comments, interpretive comments, explanations about the form of codes, or discussions about morals. Other forms of mediation, for example, limit impressions children by following the rating and parental guide guidelines.

\footnotetext{
${ }^{1}$ Sofyan Sauri, Membangun Komunikasi dalam Keluarga (Kajian Nilai Religi, Sosial, dan Edukatif) (Bandung: PT Genesindo, 2006), p. 56.

2 Q.S. Lukman/18-19.
} 
Parental mediation or parent mediation is defined by the Encyclopedia of Communication and Information as all parent-child interaction activities regarding the internet. Or the interaction of parents and children when using a media, including the internet. So, parents' efforts to overcome the effects of the internet seem to be the definition of parental mediation. ${ }^{3}$

Parent mediation as a strategy used by parents to control, supervise, and interpret mass media content for children and adolescents. ${ }^{4}$ Although researchers and mass media scholars express various definitions and steps, in general parental mediation is interpreted as a parental strategy used to control, supervise, and interpret media content.

\subsection{Media Literacy}

According to David Considine, the definition of media literacy is "The ability to access, analyze, evaluate and communicate information in a variety of formats including print and nonprint". In Considine's view, people who have experienced media literacy or who are already media literate are those who have the ability to test, analyze, evaluate, and communicate information in a variety of message formats delivered by the mass media, both print and electronic. ${ }^{5}$

David's opinion was clarified by Potter who gave the definition of media literacy as "a set of perspectives that we actively use to expose ourselves to the media to interpret the meaning of the messages we encounter". A perspective where we can actively demonstrate our ability to the media to interpret the meaning of the messages we meet. From the two opinions above, it implies that people who are literate in the media are people who have the ability to control messages from the mass media. That is, at this level the community has the ability to access, analyze, evaluate, and communicate information.

\section{Discussion}

The role of parents is very necessary in providing understanding of media literacy to their children, by regulating the amount of time used to consume media by replacing other activities that are more useful. With the presence of Smartphone, children tend to be more withdrawn from playing with friends their age, resulting in minimal interaction with their environment. Parents are expected to direct their children to learn to interact with their social environment. The widespread use of social media and Smartphone devices today tends to shape children into individualistic individuals and withdraw from social interaction because their time has been spent playing with their media devices. This allows them to enjoy playing and interacting with friends in their virtual world.

Then do not provide media, especially Smartphone to children without special supervision and to children who are toddlers. At this time many mothers have used Smartphone to keep their children quiet and manageable, but the effects produced when spoiling a child with a Smartphone will actually damage the child in terms of social.

\footnotetext{
3 Schement dalam Rakhmani, Inaya,. Hubungan Pengetahuan dan Mediasi Orangtua dengan Sikap Kritis Siswa SMA Depok Menonton Televisi, 2013, http://www.iisip.ac.id/content

${ }^{4}$ Ibid, p. 212

${ }^{5}$ Mario Antonio Birowo dan Rini Darmastuti. Literasi Media Pada Remaja Yogyakarta Dengan Berbasis Kerarifan Lokal Masyarakat Yogyakarta (Jakarta: ISKI, 2014), p. 369.
} 
Understanding media literacy can not only be given through the media itself or by using media surveillance. So far the government has been monitoring the contents of the media, but we cannot do this fully considering how much media flow has hit us, so that the public itself must be given an understanding and education of these shows, the audience must be intelligent so they can filter the messages they get, so that an understanding of media content is not only obtained through knowledge in the media but can also be obtained through educational channels starting from the elementary level to the tertiary level, both in formal and non-formal forms.

Media literacy can be provided in the field of non-formal education such as the Qur'an Education Park to the study groups and assemblies of taklim which are often carried out in residential neighborhoods or community groups, or to other religious study groups. In the formal education field media literacy can be used as a subject of local content at the level of basic education. At the high school level can be used as extracurricular activities and at the college level can be used as a supporting course. This scientific study of media literacy is not only a study of the field of communication, but an important role of education is needed to help think about how curriculum design and learning techniques are appropriate for the development of media literacy, if included in the educational curriculum at the primary, secondary level, level up to college.

The role of community organizations and religious groups in this regard is also very important and has a very large role in media literacy. The role of religious leaders in each religion is needed in providing understanding to audiences related to media content. In Islam the role of preachers who carry out $d a^{\prime} w a b$ activities to the community is urgently needed, to provide understanding to the public about media literacy. A preacher and religious figure is one of the opinion leaders in the community, this makes them have the ability to influence the audience, have the opportunity to disseminate information, have credibility in the delivery of information. This makes $d a^{\prime} i$ can be used as the spearhead in providing understanding to be more intelligent and wise in interpreting messages in the media

While in the role of regulation (control), is a limitation of the choice of behavior of other family members, who are also central in ensuring the achievement of goals within the family. Control includes communication that is essentially to limit the types of behavior directed by family members. Some family members will have more role in providing guidelines and behavioral restrictions for other family members. Forms of control roles within the family are negotiated to get the expected results from each family member. Control can be seen through discipline, intimacy negotiations, conflict, violence and unexpected interpersonal influences in the family (alcoholism, drugs, or eating disorders).

Supervision is one part of the role of regulation or control, where the same goal is to discipline the child as a family member. Supervision is an important part of family communication in addition to the role of maintenance, the role of regulation (control) plays an important function for family members, especially adolescents because teenagers are usually identical with not wanting to be controlled and the process of breaking away from the family. If the role of maintenance is useful in facilitating growth, the role of regulation contributes in disciplining children in the family. As mentioned earlier, supervision is part of the regulatory role where the aim is to supervise, limit and influence children's behavior in interacting with others. Children who are starting to grow up have a lot of interaction and socializing with their environment where the role of regulation facilitates the socialization. 
In this technological era, teenagers are already better at using the internet than parents. Wise in using its purpose is to take advantage of the internet. Actually there are so many benefits found on the internet, but the evils caused by the internet are also many. So you should be able to use your internet wisely. The benefits of using the internet are that children can develop their creativity and add insight to information from various countries. In addition, the negative impact caused by the internet for children is preferring to be alone (introvert) with their world and lack of socializing with the surrounding community. Therefore as a parent can only facilitate what is needed by their children, provided there are results obtained from the internet. Example: children can not only play games, but can also make the game themselves. If only playing more time-consuming games without results obtained.

In the Islamic perspective technological development is an inseparable part in the context of scientific development. As we know, the internet can be used as a tool to convey messages to all people throughout the world. There is much information that can be found on the internet. On the Internet there is the use of text, graphics, animation, images, video and sound to present information. Because this media can now be integrated using a computer. This very diverse application seems to share the usual assumptions-information helps people learn.

So, as the caliph. Muslims need to equip themselves with internet skills especially in improving teenage learning by making the learning process not only fun, but also effective. The internet allows teachers to use a combination of technological tools to appeal to various learning styles digitally. If well integrated, the internet also has the ability to stimulate the imagination and develop critical thinking skills while allowing teens to take an active role in their own learning.

Many Muslims do not realize how important technology is. Through the internet, information about Islam can be introduced and implemented. As what the Prophet Muhammad SAW said, "The search for knowledge is obligatory for every Muslim" (AlTirmidhi, Hadith 74) ". Therefore, as a Muslim, it is obligatory to learn and master internetrelated skills to spread the teachings of Islam. From the results of the discussion above, the researcher made a design model of internet media literacy in Muslim families.

Table 4. Media Literacy Model in Muslim Families

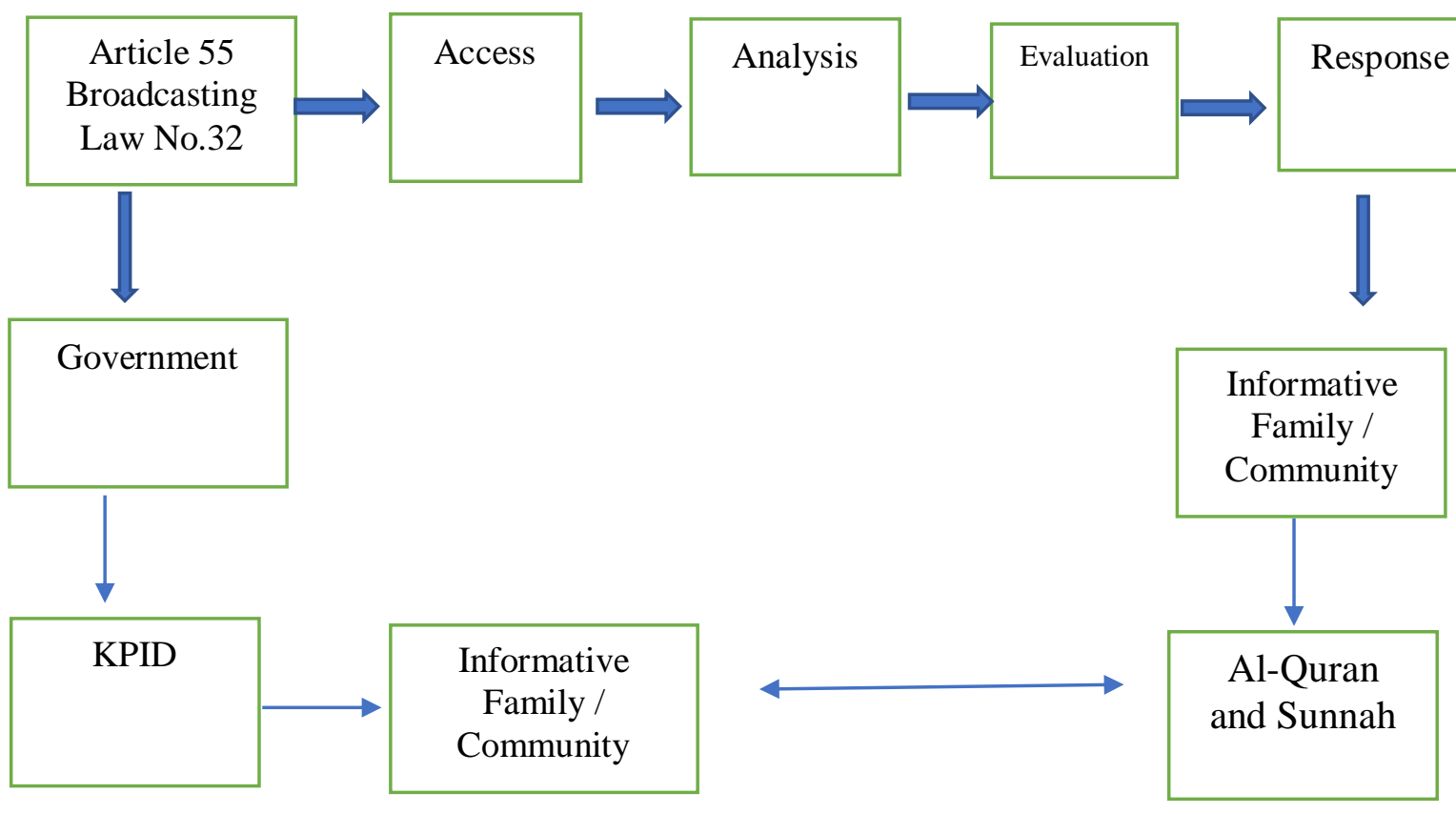


Associated with the media literacy model, one of the ways applied by families to filter the exposure of internet media in family life is togetherness and kinship and instilling Islamic values so as to create a smart, literate and informative family in the use of the internet.

From this embedded value the excessive and useless use of the internet has no place in the family. They are guided by the Al-Qura'an and sunnab and other Islamic values in instilling internet media literacy.

\section{Conclusion}

Way of supervision carried out by parents in connection with regarding the negative impact of using the internet, parents' informants do direct supervision, although the form of direct supervision is different in each family, but basically parents are present near their teenagers when teens use the internet.

Technically, parents directly or check the internet access activities on their child's laptop and be close to their teenagers when using the internet not by prohibiting, but by continuing to ask questions about children's play activities on the internet, this step is taken by parents to find information about the patterns of playing teenagers they are on the internet, in addition, this initial step also forms the basis of implementing supervision or supervisory decisions that are intended to be carried out to their children.

Dialogue is carried out with face-to-face communication between mothers and adolescents, where dialogue is the most effective form of communication to provide an understanding for adolescent children about the impact of using internet social networking sites. Provision of understanding to adolescents is a further step of the supervision process carried out by parents to their teens.

Dialogue is carried out with face-to-face communication between mothers and adolescents, where dialogue is the most effective form of communication to provide an understanding for adolescent children about the impact of using internet social networking sites. Provision of understanding to adolescents is a further step of the supervision process carried out by parents to their teens. Provision of understanding between parents and adolescents is classified into interpersonal communication because in essence interpersonal communication is dyadic communication that is face-to-face communication which is the process of delivering messages between a communicator and a communicant in order to reach understanding. This type of communication is considered the most effective way to change attitudes, opinions, or human behavior due to dialogical processes.

\section{References}

An, Kyoung Seon and Lee, Doohwang. An Integrated Model of Parental mediation: The effect of Family Communication on Children's Perseption of Televisi

Aufderheide, P, (1993). Media Literacy: A Report of the National Leadership Conference on Media Literacy. Aspen. Aspen Institute.

Berger, Charles R, et. al, (2014) Handbook Ilmu Komunikasi Bandung: Nusa Media,

Birowo, Mario Antonio, and Rini Darmastuti, (2014) Literasi Media Pada Remaja Yogyakarta Dengan Berbasis Kerarifan Lokal Masyarakat Yogyakarta Jakarta: ISKI,.

Birowo, Mario Antonius, (2012). Perspektif Budaya Dalam Literasi Media. Artikel dalam Buku Literasi Media dan Kearifan Lokal. Yogyakarta: Buku Litera. 
Budiastuti, Wiratmo, (2012). Literasi Media Berbasis Komunitas. Artikel dalam Buku Gerakan Literasi Media. Rumah Sinema. Yogyakarta: Rumah sinema.

Bungin, Burhan, (2008). Sosiologi Komunikasi. Jakarta: Kencana Prenada.

Buerkel-Rothfuss \& Buerkel, (2001) Dalam Kyoung Seon dan Lee, Doohwang, An Integrated Model of Parental Mediation: The effect of Family Communication on Children's Perseption of Televisi.

Buckingham, David, (2007) Media Education: Literacy, Learning And Contemporary Culture. Cambridge: Polity Press.

Bujizen \& Valkenburg. 2005. Dalam Mendosa, Kelly. Surveying Parental Mediation: Connections, Challenges and Questions for Media Literacy. (The National Association for Media Literacy Education's Journal of Media Literacy Education, 2009)

Darajat, Zakiah, (1988) Kesehatan Mental. Jakarta : Gunung Agung.

Darmastuti, Rini et. al, (2012) Literasi Media dan Kearifan Lokal: Konsep dan Aplikasi. Yogyakarta: Mata Padi Pressindo.

Departemen Pendidikan Dan Kebudayaan, (1990) Kamus Besar Bahasa Indonesia. Jakarta: Balai Pustaka.

Devito, Joseph A, (2008)Essentials of Human Communication. Sixth Edition. Boston: Pearson Education, Inc.

Djamarah, Syaiful Bahri, (2014) Pola Komunikasi Orang Tua \& Anak Dalam Keluarga. Jakarta: Rineka Cipta,

Dyson P, Laurentius dan Emanuel, ( 2013 ). Kebijakan Tentang Budaya Lokal. UNESA: Fakultas Bahasa dan Seni.

Effendy, Onong Uchjana, (1984) IImu Komunikasi (Teori dan Praktek). Jakarta: PT. Remaja Karya.

Faizal, Ahmad Riza, (2012). Apa Makna Literasi Media Sesunggubnya? Artikel dalamBuku Meretas Jalan Sosialisasi Literasi Media di Indonesia. KPI Pusat.

Fahmi, Abu Bakar, (2011). Mencerna Situs Jejaring Sosial: Bagaimana Situs Jejaring Sosial Membantu Memahami Diri Sendiri dan Orang Lain. Jakarta: PT Elex Media Komputindo.

Grisanti, (1990). Seni Mendisplin Anak. Jakarta: Mitra Utama.

Griffin, EM, (2003). A First Look at Communication Theory. New York: McGraw Hill.

Hallahan, Kirk, at.al, (2007) Defining Strategic Communication. International Journal of Strategic Communication, London: Lawrence Erlbaum Associates, Inc.

Hendra, Y. (2019). Family Communication Model in Forming Pious Children. Budapest International Research and Critics Institute (BIRCI-Journal), 28-38

Ilahi, Wahyu, (2010). Komunikasi Dakwah. Bandung: PT.Remaja Rosdakarya.

Kellner, Douglas, (2010). Media Culture: Cultural Studies, Identity and Politics Between The Modern and The Postmodern. Routledge. London and New Yorks.

Kellner, Douglas, (2010). Budaya Media: Cultural Studies, Identitas dan Politik: Antara Modern dan Postmodern. Yogyakarta: Jalasutra.

Kartini, Kartono, (1979). Psikologi Anak. Bandung: Alumni.

Kristin Zolten \& Nicholas Long, (2006). Parent and Child Communication. Arkansas: University of Arkansas.

McQuail, Denis, (2011). Teori Komunikasi Massa,Terj. Putri Iva Izzati, buku 1, Edisi. 6. Jakarta: Salemba Humanik.

Morisan, (2013). Teori Komunikasi Individu Hingga Massa. Jakarta: Kencana.

Moleong, Lexy J, (2014) Metodologi Penelitian Kualitatif. Bandung: PT.Remaja Rosdakarya.

Mowlana, Hamid, (1998). Covering Islam: Media and Its Impact on Muslim Identity. International Conference Muslim Identity in $21^{\text {st }}$ Century: Challenges of Modernity". School of Oriental and African Studies, University of London. 
Mulyana, Deddy, (2002). Ilmu Komunikasi: Suatu Pengantar. Bandung: PT Remaja Rosdakarya.

Mulyana, Deddy, (2011). Mau ke Mana Ilmu Komunikasi Kita. Dalam Deddy Mulyana. Ed. Ilmu Komunikasi: Sekarang dan Tantangan Masa Depan. Jakarta: Kencana.

Mulyanto. Agus, (2009). Sistem Informasi Konsep \& Aplikasi. Yogyakarta: Pustaka Pelajar.

Mutadi, Asep Saeful, (2010). Komunikasi Dakwah Teori, Pendekatan, Dan Aplikasi. Bandung: Simbiosa Rekatama Media.

Muntaha, Ahmad, (2011). Berpisah Menyatu dan Berbagi Ruang Rindu di Media Baru: Pengalaman Komunikasi Online Tiga Nettie-Family Indonesia. Dalam Deddy Mulyana. Ed. Ilmu Komunikasi: Sekarang dan Tantangan Masa Depan. Jakarta: Kencana,.

Neuman, W. Lawrence, (2010). Social Reseach Methods: Qualitative and Quantitative Approaches. Boston: Allyn and Bacon, 2010.

Pawito, (2008). Penelitian Komunikasi Kualitatif. Yogyakarta: LKIS.

Potter, James. W, (2004). Theory of Media Literacy: a Cognitive Approach. California: Sage Publications. California.

Potter, James, (2008). Media Literacy (4th ed.). California: Sage Publications Inc.

Potter, W. James, (2009). Media Literacy, Dalam William F. Eadie, 21 ${ }^{\text {st }}$ Century Communication: A ReferenceHandbook Volume 1 \& 2. London: SAGE.

Rahardjo, Turnomo, (2012). Memahami Literasi Media. Artikel dalam Buku Literasi Media dan Kearifan Lokal. Yogyakarta: Buku Litera.

Sendjaja, Djuarsa, (1999). Pengantar Komunikasi. Jakarta: Universitas Terbuka. Straubhar, Joseph \& Robert Larose, (2008) Media Now: Communication Media in the Information Age. Australia: Wodsworth Thomson Learning.

Sauri. Sofyan, (2006). Membangun Komunikasi dalam Keluarga (Kajian Nilai Religi, Sosial, dan Edukatif). Bandung: PT Genesindo.

Strommen dan Fitzgerald dalam D. Singgih Gunarsa, (1987). Psikologi Untuk Keluarga. Jakarta: Gunung Mulia.

Tri Sari Arum. (2014). Literasi Media Televisi pada Orang Tua dan Implikasinya terbadap Perilaku Menonton Anak., (Ejournal Ilmu Komunikasi).

Warren Ron. (2005). Parental Medoation of Children is Televitions Viewing in Low Income Famillies, Jurnal of Communication. 